\title{
Pengaruh Current Ratio (Cr) dan Debt To Equity Ratio Terhadap Return On Equity pada PT. Indah Kiat Pulp \& Paper, Tbk Periode 2012-2018
}

\author{
Nina Shabrina \\ Program Studi Manajemen, Fakultas Ekonomi, Universitas Pamulang \\ dosen01567@unpam.ac.id
}

\begin{abstract}
How to cite (in APA style):
Shabrina, N. (2020). Pengaruh Current Ratio (Cr) dan Debt To Equity Ratio Terhadap Return On Equity pada PT. Indah Kiat Pulp \& Paper, Tbk Periode 2012-2018. 19(2), pp.98-107. https://doi.org/10.22225/we.19.2.1966.98-107
\end{abstract}

Abstract

The purpose of this study was to find out and give empirical study thru the effect of Current Ratio (CR) and Debt to Equity Ratio (DER) in la partially and simultaneously on the Return On Equity (ROE) at PTIndah Kiat Pulp \& Paper, Tbk for the period 2012-2018. The research method uses secondary data in the form of financial statements of PT Indah Kiat Pulp \& Paper, Tbk and data analysis using multiple linear regression, classic assumptions test which include the normality, multicollinearity, heteroscedasticity and Autocorrelation tests, with hypothesis tests. The results showed that the Current Ratio (CR) and Debt to Equity Ratio (DER) has simultaneous influenceto the Return On Equity meanwhile each of Current Ratio and Debt to Equity Ratio has no influence to the Return On Equity.

Keywords: Current ratio; debt to equity ratio; return on equity.

Abstrak

Tujuan penelitian ini adalah untuk mengetahui dan memberi bukti empiris atas pengaruh Current Ratio (CR) dan Debt to Equity Ratio baik secara parsial maupun simultan terhadap Return On Equity (ROE) pada PT Indah Kiat Pulp \& Paper, Tbk periode 2012-2018. Metode penelitian menggunakan data sekunder berupa laporan keuangan PT Indah Kiat Pulp \& Paper, Tbk serta analisis data menggunakan regresi linier berganda, pengujian asumsi klasik yang meliputi: Uji Normalitas, Multikolinearitas, Heteroskedastisitas serta Uji Autokorelasi, dan Uji Hipotesis. Hasil penelitian menunjukkan bahwa Current Ratio dan Debt to Equity Ratio berpengaruh secara simultan terhadap Return On Equity sementara Current Ratio dan Debt to Equity Ratio masing-masing tidak berpengaruh secara parsial terhadap Return On Equity.

Kata kunci: current ratio; debt to equity ratio; return on equity.

\section{PENDAHULUAN}

Perusahaan makanan dan minuman merupakan salah satu kategori sektor industri di Bursa Efek Indonesia (BEI) yaitu sub sektor pulp dan kertas yang masih berpeluang untuk tumbuh dan berkembang.Pergerakan harga saham menjadi bidang kajian yang menjadi perhatian dalam kurun waktu terakhir pada dengan temuan hasil riset yang beragam.Keputusan investasi merupakan titik yang penting, dimana menjadi motor penggerak utama lini usaha tersebut. Perusahaan pada sektor ini dihadapi tantangan digitalisasi di era informasi dengan konsep paperless, meskipun demikian pada Rapat Kerja Asosiasi Pul dan Kertas Indonesia (APKI) yang dilaksanakan di JIEXpo Kemayoran, optimistis Direktur Hasil Hutan dan Perkebunan akan pertumbuhan industri domestik dengan melihat permintaan global yang masih berada di angka 2-4 persen (Pablo, 2018).

Pentingnya inovasi dalam teknologi yang sesuai dengan implementasi Making Indonesia 4.0, sehingga menciptakan peluang lebih untuk masuk ke pasar global, hal ini sebagai dasar bagi industri kertas untuk meningkatkan kapasitas produksinya dalam rangka perluasan segmen bisnis (Kontan, 2019). Pada tahun 2018, seperti halnya dengan produsen kemasan berbasis kertas PT Fajar Surya Wisesa Tbk beroperasi dengan kapasitas produksi baru, setelah mengakuisisi pabrik kertas yang sebelumnya dimiliki PT Surabaya Agung Industri Pulp \& Paper(PT Fajar Surya Wisesa, Tbk., 2019). Contoh lainnya adalah PT Indah Kiat Pulp\& Paper, Tbk. yang memiliki 3 sektor bisnis (pulp, kertas dan kemasan) terus berupaya untuk memperluas cakupan bisnisnya pada segmen non- 
kertas dengan cara memperluas kapasitas produksinya dalam bisnis tisu pada tahun ini hingga 108.000 ton per tahun (Arief, 2018).

Langkah-langkah strategis yang diambil perusahaan ini tentunya memiliki tujuan akhir yaitu kemakmuran pemegang saham dan meningkatkan harga saham perusahaan.Oleh sebab itu, setiap perusahaan harus memperhatikan kualitas dan kuantitas produksinya sesuai dengan kebutuhan konsumen serta sebagai distributor, sebagai mata rantai penyaluran barang dalam rangka melayani konsumen agar barang yang dibutuhkan sampai pada konsumen tepat waktu, tepat tempat, tepat sasaran, tepat kuantitas, dan tepat kualitas sehingga barang yang dibutuhkan masyarakat dapat dengan mudah diperoleh.

Profitabilitas merupakan kebijakan pengukuran kinerja yang berperan penting dalam suatu perusahaan. Perhitungan ini berdasarkan keuntungan usaha yang dihasilkan oleh nasabah dengan return kepada investor berupa feedback rate tidak hanya berdasarkan pendapatan atau penjualan (Yanti, 2018). Oleh karenanya, rasio keuangan memiliki dampak penting bagi pihak-pihak yang terlibat didalamnya seperti perusahaan, pemegang saham dan kreditursebagai alat ukur kinerja perusahaan. Selain itu, Return on Equity (ROE)juga menjadi pengukuran profitabilitas yang banyak digunakan oleh peneliti selain Return on Asset (ROA), kedua rasio ini menggambarkan daya tarik investasi (Husain dkk., 2020). Faktor-faktor yang mungkin dapat mempengaruhi profitabilitas antara lain rasio likuiditas yang diproksikan dengancurrent ratio dan leverage dengan pengukurandebt to equity ratio (DER).

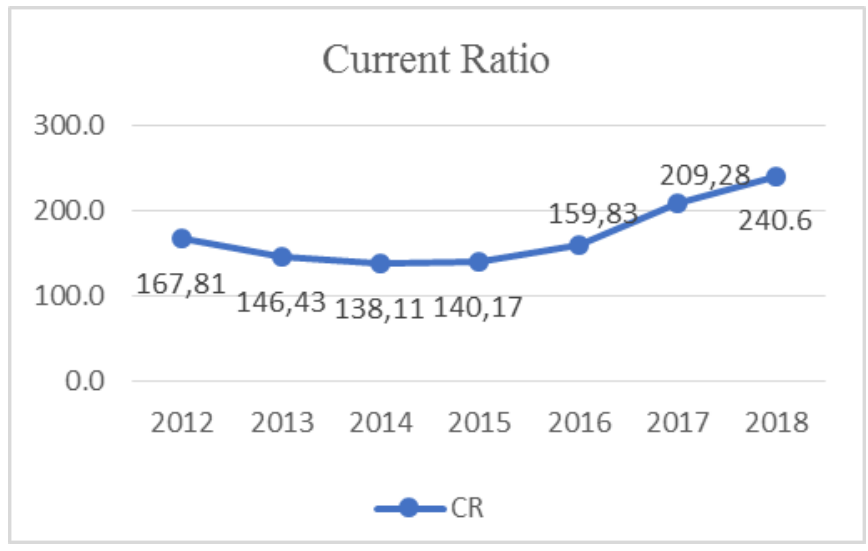

Gambar 1

Grafik Rasio Tingkat Current Ratio (CR) pada

PT Indah Kiat Pulp \& Paper Tbk periode $2012-2018$

Berdasarkan Gambar 1 menunjukkan data rasio bersifat fluktuatif. Adapun rasiolancar pada tahun2012 sebesar 167,81 persen atau 1,68 kalimenurun hingga tahun 2014 sebesar 146,43 persen atau 1,46 kali sementara nilai CRdi tahun 2015 sebesar 140,17 persen atau 1,47 kali berfluktuasi hingga tahun 2018 dengan nilai paling tinggi sebesar 240,86 persenatau 2,41 kali. Data ini tentunya secara ilmiah menjadi menarik untuk diteliti mengingat pada periodew2012-2014 serta periode 20152018 memiliki arah fluktuasi yang tidak searah.Rasio lancar (current ratio) dapat dikatakan sebagai bentuk untuk mengukur tingkat keamanan (margin of safety) suatu perusahaan. Perhitungan rasio lancar dilakukan dengan cara membandingkan antara total aset lancar dengan total utang lancar.Dari hasil pengukuran rasio, apabila rasio lancar lebih rendah, dapat dikatakan bahwa perusahaan kurang modal untuk membayar utang.Namun, apabila hasil pengukuran rasio tinggi, belum tentu kondisi perusahaan sedang baik dikarenakan kas tidak digunakan dengan sebaik mungkin.

Rasio lancar merupakan salah satu alat pengukuran kinerja yang berfungsi untuk menilai kemampuan suatu perusahaan untuk memenuhi kewajiban keuangannya yang harus segera dipenuhi, atau kemampuan perusahaan untuk memenuhi kewajiban keuangannya pada saat ditagih (Kasmir, 2016). Menurut Keown (2011), rasio inidihitung dengan membandingkan kas dan aset-aset yang dapat diubah dalam bentuk kas pada tahun dimana kewajiban jatuh tempo dan akan dibayar pada tahun itu juga (Subramanyam, 2014-546). 


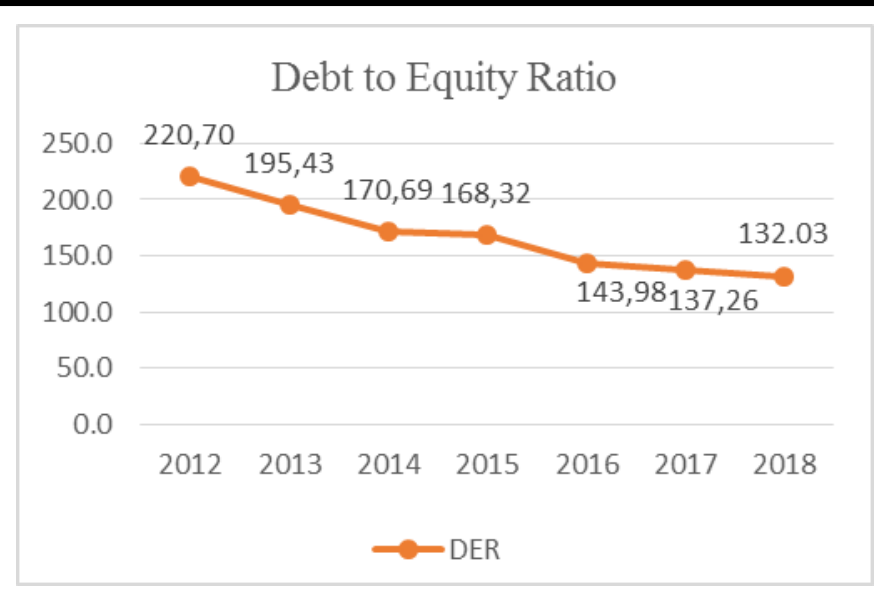

Gambar 2

Grafik Rasio Tingkat Debt to Equity Ratio (DER) pada

PT Indah Kiat Pulp \& Paper Tbk periode $2012-2018$

Berdasarkan Gambar2 menunjukkan data rasio bersifat fluktuatif. Adapun rasioleveragepada tahun2012 sebesar 220,70 persen atau 2,207 kalimenurun hingga tahun 2015 sebesar 168,32 persen atau 1,68 kali sementara nilai DER di tahun 2016 sebesar 143,98 persen atau 1,44 kali berfluktuasi hingga tahun 2017 dengan nilai paling terendah sebesar 137,26 persenatau 1,37 kali. Data ini tentunya secara ilmiah menjadi menarik untuk diteliti mengingat pada periode 2012 hingga 2018 memiliki arah fluktuasi yang searah dan selalu menurun. Rasio Debt to Equity Ratio (DER) merupakan rasio yang digunakan untuk menilai utang dengan ekuitas. Rasio ini dicari dengan cara membandingkan antara seluruh utang termasuk utang lancar dengan seluruh ekuitas.

Rasio DER merupakan salah satu alat pengukuran kinerja yang berfungsi untuk menilai kemampuan suatu perusahaan untuk membiayai kewajiban perusahaan dengan hutang, atau mengukur sejauhmana aset perusahaan dibiayai oleh hutang (Kasmir, 2016). Rasio inidigunakan umumnya oleh perusahaan yang menggunakan pendanaan baik utang maupun ekuitas. Rasio ini dikenal dengan istilah leverage perusahaan dapat didefinisikan sebagai jumlah pendanaan utang dalam struktur modal suatu perusahaan (Subramanyam, 2014:565).

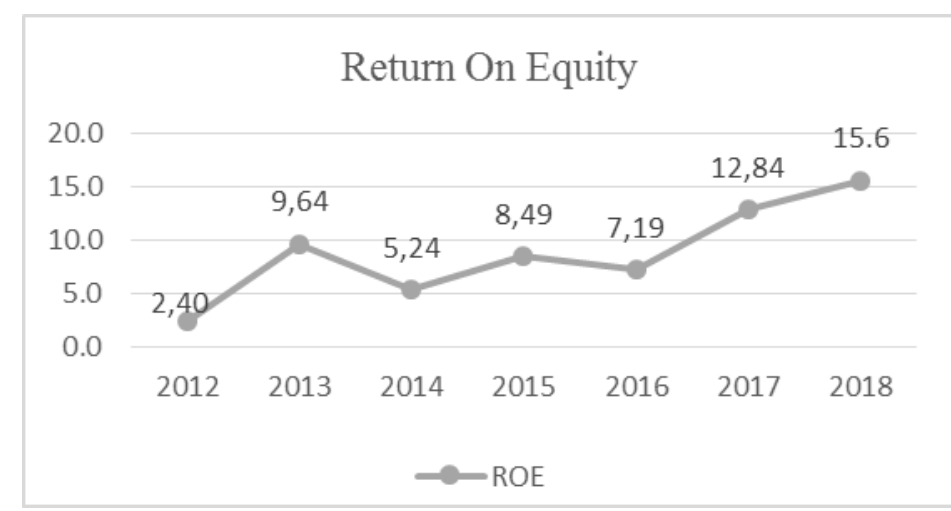

Gambar 3

Grafik Rasio Tingkat Return On Equity (ROE) pada

PT Indah Kiat Pulp \& Paper Tbk periode $2012-2018$

Berdasarkan Gambar3 menunjukkan data rasio bersifat fluktuatif. Adapun rasioROE pada tahun2012 sebesar 2,4 persen meningkat di tahun 2013 sebesar 9,64 persen sementara pada 5,24 persendi tahun 2014 dan meningkat di tahun 2015 menjadi 8,49 persen. Sejaktahun 2016sebesar 7,19 persen terus berfluktuasi hingga tahun 2018 sebesar 15,6 persen dan tertinggi. Data ini tentunya secara ilmiah menjadi menarik untuk diteliti mengingat pada periode 2012 hingga 2018 memiliki arah fluktuasi yang searah dan sejak 2016 meningkat hingga periode 2018. Rasio Return On Equity (ROE) yang menjadi dampak dari faktor CR dan DERmenggambarkan kinerja keuangan dari PT In- 
dah Kiat Pulp \& Paper Tbk periode 2012 - 2018.

Beberapa hasil penelitian terdahulu yang dikaji antara lain: (1) Penelitian tahun 2017 yang menggunakan sampel perusahaan Makanan dan Minuman periode 2011-2015 sebanyak 12 sampel perusahaan, dengan temuan riset yang menguji pengaruh Manajemen Modal Kerja terhadap profitabilitas dengan arah positif dan signifikan sedangkan perputaran kas dan perputaran persediaan berpengaruh terhadap profitabilitas (ROI) dengan arah negatif (Sapetu dkk., 2017). (2) Penelitian tahun 2018 yang mengkaji perkembangan Current Ratio (CR), Debt To Equity (DER), Return on Asset (ROA) dan mengetahui signifikansi pengaruh variabel CR dan DER, baik secara parsial maupun secara bersama sama terhadap ROA pada PT. Astra International Tbk. Hasil penelitiannya menunjukkan bahwa Current ratio mempunyai koefisien regresi sebesar -1.391 dan tingkat signifikan sebesar 0.207. Hal ini berarti H1 ditolak sehingga dapat dikatakan bahwa Current ratio berpengaruh namun tidak signifikan terhadap Return on asset, variable debt to equity mempunyai koefisien regresi sebesar -0.811dan tingkat signifikasi sebesar 0.444 . Hal ini berarti $\mathrm{H} 2$ ditolak sehingga dapat dikatakan bahwa debt to equity berpengaruh namun tidak signifikan terhadap Return on asset karena tingkat signifikasi yang dimiliki variable debt to equity lebih besar dari 0.05, Berdasarkan hasil penelitian diperoleh nilai $\mathrm{F}$ sebesar 0.994 dengan tingkat signifikasi 0.417 . Karena tingkat signifikasi lebih besar dari 0.05, maka dapat dikatakan bahwa hipotesis $\mathrm{H} 3$ ditolak, yaitu Current ratio, debt to equity berpengaruh namun tidak signifikan terhadap Return on asset, (Wartono, 2018). (3) Penelitian tahun 2019, mengkaji tentang pengaruh Current Ratio, Debt to Asset Ratio, Perputaran Modal Kerja terhadap Return on Asset pada perusahaan sektor industri barang komsumsi yang terdaftar di Bursa Efek Indonesia tahun 2013-2017. Hasil penelitian ini menunjukkan bahwa secara simultan variabelvariabel indepeden; Current Ratio, Debt to Asset Ratio, Perputaran Modal Kerja dengan uji F, secara bersama-sama berpengaruh terhadap Return on Asset. Hasil secara parsial dengan uji T, variabel Debt to Asset Ratio berpengaruh terhadap Return on Asset, Sedangkan Current Ratio, Perputaran Modal Kerja tidak berpengaruh dan tidak signifikan terhadap Return on Asset. (4) Penelitian tahun 2019 yang menggunakan sampel perusahaan Telekomunikasi periode 2013-2017 pada Jakarta Islamic Index (JII), dengan temuan riset yang menguji pengaruhcurrent ratio terhadap return on equitydengan tidak membuktikan signifikansinya semetara debt to equity ratio berpengaruh positif dan signifikan terhadapreturn on equity (Rahmah \& Asnawi, 2019). (5) Penelitian yang juga di tahun 2019yaitu studi kasus pada PT Astra International, Tbk selama 2012-2016 yang bertujuan menganalisis rasio profitabilitas dan rasio likuiditas dalam rangka menilai kinerja keuangan perusahaan.Hasil penelitian ini dengan pengukuran dengan Rasio Profitabilitas dengan Gross Profit Margin (GPM) mengalami kenaikan dan penurunan,yaitu 15\%,14\% 13\%, 10\% dan 12\% dengan standar industri sebesar 30 persen, sementaraReturn on Equity (ROE) dengan $25 \%, 21 \%, 18 \%, 13 \%$ dan 14\%dengan standar industri sebesar 40 persen. Rasio Likuiditas (Current Ratio) mengalami kenaikan dan penurunan $140 \%, 120 \%, 140 \%, 140 \%, 120 \%$, dengan standar industri sebesar 200 persen dan Quick Ratio (QR) mengalami kenaikan dan penurunan, 110\%, 103\%, 109\%, 113\% dan 104\% dengan standar industri sebesar 150\% (Shabrina, 2019). (6) Penelitian tahun 2020 yaitu studi pada 11 perusahaan sub sektor otomotif dan komponen selama tahun 2014-2018 yang bertujuan untuk memprediksi nilai perusahaan menggunakan prediktor profitabilitas dan dividen dengan temuan yang gagal membuktikan pengaruh rasio profitabilitas terhadap kebijakan dividen serta dampaknya kinerja perusahaan (Husain dkk., 2020).

Berdasarkan keragaman temuan penelitian terdahulu, mendasari penelitian ini untuk dikaji lebih lanjut dengan studi yang bertujuan untuk mengetahui dan menganalisis bukti empiris atas pengaruh Current Ratio (CR) dan Debt to Equity Ratio (DER) terhadap Return On Equity (ROE) menjadi paradigma berpikir yang diturunkan ke dalam suatu model penelitian. Model itu sendiri dapat didefinisikan sebagai konstruksi melalui parameter spesifik yang diukur baik dalam struktur, bentuk, isi, jumlah dan makna dengan segala keterbatasan (Husain, 2019). Oleh karena itu, model penelitian ini dapat dilihat pada Gambar 4.

\section{METODE}

Jenis penelitian ini adalah riset kausalitas yang bertujuan untuk mencari penjelasan dalam bentuk hubungan sebab-akibat (causal effect) antar beberapa variabel. Penelitian ini merupakan applied research untuk mencari faktor penyebab timbulnya masalah sehingga hasilnya dapat digunakan sebagai dasar pemecahan langkah-langkah perbaikan (Supranto \& Limakrisna, 2019, hal. 
3).Pendekatan kuantitatif digunakan untuk mengobservasi atau mengukur data-data angka yang berasal dari Bursa Efek Indonesia (BEI) yang dapat diakses secara online melalui website resmi perusahaan PT Indah Kiat Pulp \& Paper, Tbk dan www.idx.co.id. Populasi adalah wilayah yang digeneralisasi atas subyek atau obyek yang mempunyai kualitas dan karakteristik tertentu yang ditetapkan oleh peneliti untuk dipelajari dan kemudian ditarik kesimpulannya (Sugiyono, 2018:117). Pengambilan sampel dilakukan sebagai upaya untuk menetapkan bagian dari populasi dengan mempertimbangkan representasi dari elemen populasi untuk memperoleh data dan informasi penelitian (Indrawati, 2015). Sumber data penelitian ini meliputidata sekunder yaitu data yang diperolehdari Bursa Efek Indonesia yaitu PT Indah Kiat Pulp \& Paper, Tbk. yang berupa laporan neraca dan laporan laba rugi periode 2012hingga 2018 sehingga diperoleh informasi yang cukup untuk menggambarkan kinerja laporan keuangan perusahaan. Metode analisis data adalah proses mencari dan menyusun secara sistematis data yang diperoleh dari hasil wawancara, catatan lapangan, dokumentasi, dan bahan-bahan lain, sehingga dapat mudah dipahami dan temuannya dapat di informasikan kepada orang lain (Sugiyono, 2018:244). Teknik analisis menggunakan regresi linear berganda dengan bantuan program Statistical Package for Social Science (SPSS) Versi 21. Tahapan analisis data dilakukan antara lain: (i) analisis rasio keuangan melalui uji deskriptif statistik; (ii) uji asumsi klasik dengan normalitas, multikolinearitas, heteroskedastisitasdan uji autokorelasi; dan (iii) analisisregresi berganda dengan persamaan $\mathrm{Y}=\mathrm{a}+\mathrm{b}_{1} \mathrm{X}_{1}+\mathrm{b}_{2} \mathrm{X}_{2}+\mathrm{e}$; (iv)koefisien determinasi $\left(\mathrm{R}^{2}\right)$ untuk mengetahui seberapa besar kemampuan variabel independen menjelaskan variabel dependen; (v) uji Koefisien Regresi Secara Parsial (Uji t) dengan syarat apabila t hitung $>$ t tabel maka variabel $\mathrm{X}$ secara parsial atau individual berpengaruh terhadap variabel $\mathrm{Y}$ atau sebaliknya; dan (vi) uji koefisien regresi secara simultan dengan syarat apabila $\mathrm{f}$ hitung $>\mathrm{f}$ tabel atau menghasilkan

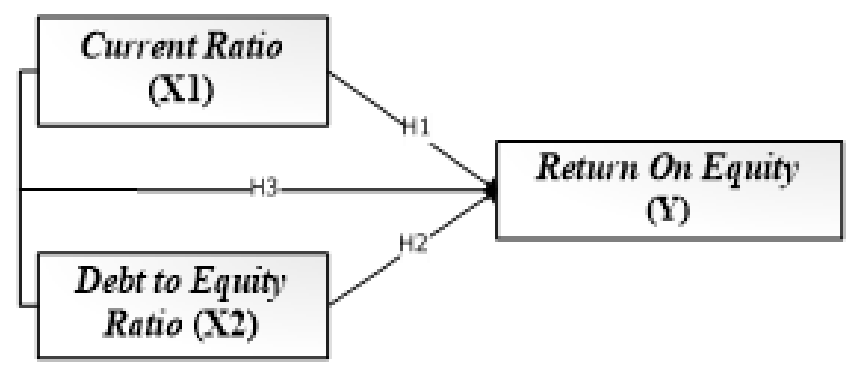

Gambar 4

Model Penelitian

Hipotesis penelitian ini dirumuskan sebagai berikut:

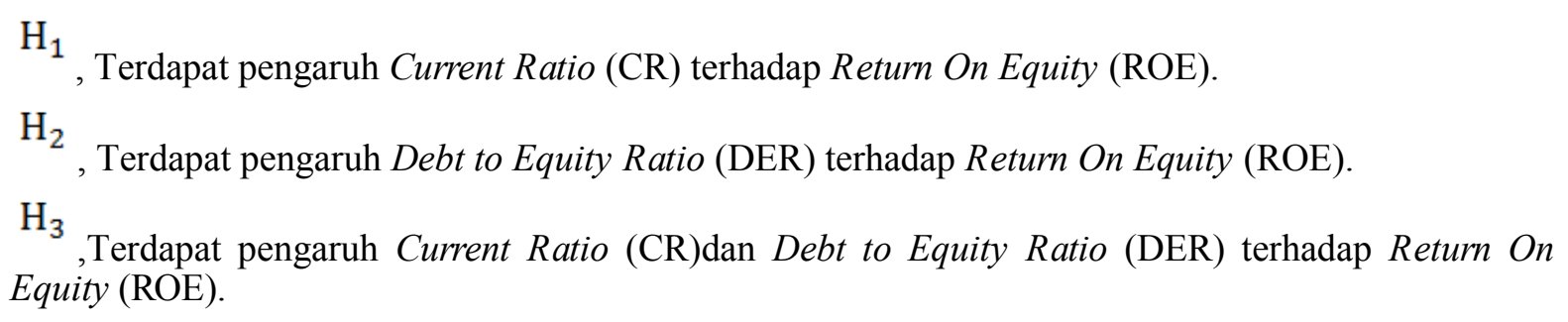
probabilitas signifikansi kurang dari alpha 5 persen maka variabel $\mathrm{X}$ berpengaruh terhadap variabel $\mathrm{Y}$ atau sebaliknya.

\section{HASIL PENELITIAN DAN PEMBAHASAN}

\section{Hasil Penelitian}

PT Indah Kiat Pulp \& Paper, Tbk. (selanjutnya disebut perusahaan) didirikan pada tahun 1976. Perusahaan berdomisili di Tangerang dengan pabrik berlokasi di Tangerang dan Serang - Banten. Kantor Pusat beralamat di Sinar Mas Land Plaza, Jl. M.H. Thamrin, No.51,Rt.9/4,Menteng, Jakarta Pusat - 10350. Perusahaan mulai beroperasi pada tanggal 1 Juni 1979 dengan dilakukan produksi komersil sekaligus karena bertepatan dengan tanggal kelahiran Bapak Soetopo, dan pembuatan logo 
dan motto : "Turut membangun negara, mencerdaskan bangsa dan melestarikan lingkungan".

Perusahaan bergerak di bidang pulp dan produk kertas dengan kualitas sesuai persyaratan secara konsisten, menghasilkan produk-produk dengan harga yang wajar dan bersaing, pengiriman dan pelayanan yang tepat waktu Paper.

\section{Uji Deskriptif Statistik}

Tabel 1

Hasil Statistik Deskriptif

\begin{tabular}{cccc}
\hline \multicolumn{4}{c}{ Descriptive Statistics } \\
\hline & Mean & Std. Deviation & $\mathrm{N}$ \\
ROE (Y) & 8.7714 & 4.46436 & 7 \\
CR (X1) & 171.7471 & 38.89405 & 7 \\
DER (X2) & 166.9157 & 32.51808 & 7 \\
\hline
\end{tabular}

Sumber: Output SPSS 21.00 (2019)

Tabel 1 menyajikan data pada 7 observasi pada PT Indah Kiat Pulp \& Paper, Tbk. dengan variabel return on equity (Y) memiliki skor rata-rata 8,7714 persen, artinya tingkat pengembalian laba bersih atas rata-rata keseluruhan ekuitas yang dimiliki perusahaan cukup rendah.Variabel current ratio (X1) memiliki skor rata-rata 1,717 kali, artinya aset-aset kategori lancar yang memiliki jangka waktu kurang dari satu tahun cukup likuid. Variabel debt to equity ratio (X2) memiliki skor rata-rata 1,669 kali, artinya tingkat leverage perusahaan dalam rangka memenuhi kewajiban yang segera jatuh tempo cukup cepat.

\section{Uji Asumsi Klasik}

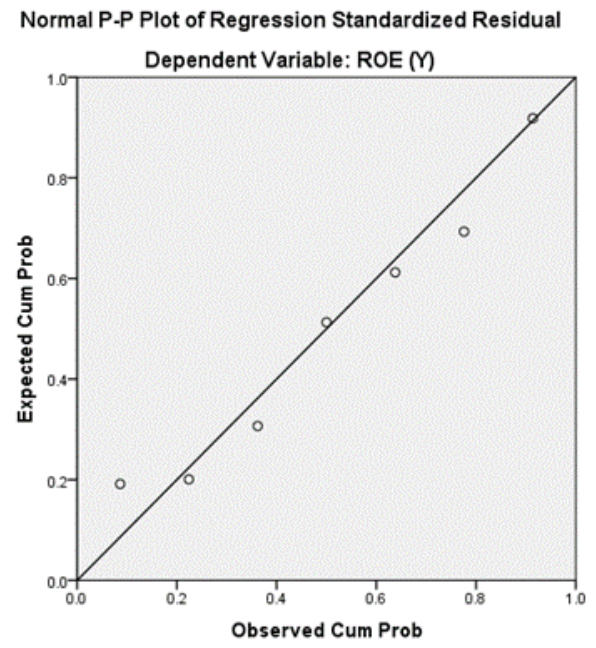

Gambar 5

Hasil P-Plots

Gambar 5 memperlihatkan grafik p-plotsyang menyebardi titik-titik pada garis diagonal dan mengikuti arah garis diagonal, yang artinyabahwa model regresi memenuhi asumsi normalitas. Selain itu, uji normalitas juga dapat dilakukan dengan melihat grafik histogram.

Gambar 6 memperlihatkan nilai residual data telah menunjukkan kurva normal yang membentuk lonceng sempurna. 


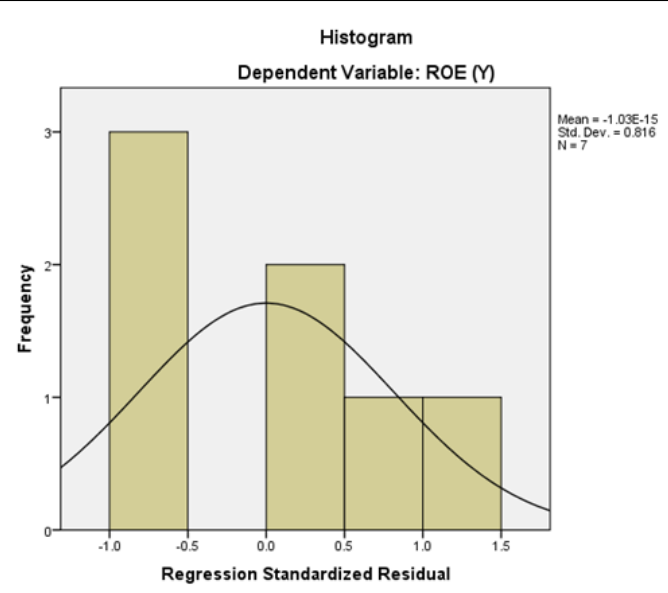

Gambar 6

Histogram Uji Normalitas

Tabel 2

Hasil Uji Multikolinearitas

\begin{tabular}{ccc}
\hline Variebel & Nilai VIF & Nilai Tolerance \\
\hline Current Ratio (X1) & 1,488 & 0,672 \\
Debt to Equity Ratio (X2) & 1,488 & 0,672 \\
\hline
\end{tabular}

Sumber: Data diolah SPSS 21.00 (2019)

Tabel 2di atas menghasilkan skorvariance inflation factor (VIF) yang kurang dari 10dan skor tolerance yang jauh lebih besar dari 1 untuk kedua variabel independen, yang artinya tidak ada permasalahan multikolinearitas yang terjadi antar variabel independen.

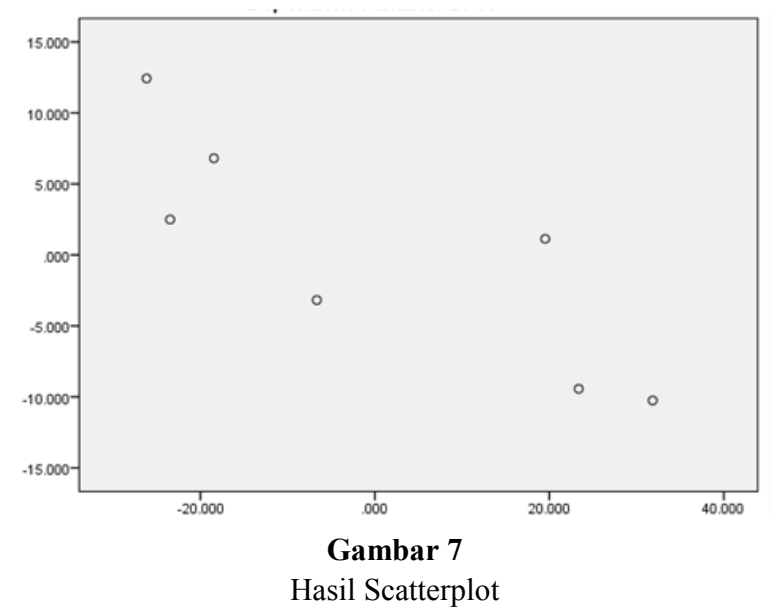

Gambar 7 memperlihatkan grafik scatterpolotyang terlihat menyebar secara acak serta tersebar baik diatas maupun dibawah angka 0 pada sumbu $Y$ yang artinyatidak terjadi heteroskedastisitas pada model regresi.

\section{Tabel 3}

Hasil Uji Autokorelasi

\begin{tabular}{cccc}
\hline Skor & dL & dU & dW \\
$\mathrm{k}: 2, \mathrm{n}: 7$ & 0,294 & 1,676 & 3,089 \\
\hline
\end{tabular}

Sumber: Data diolah SPSS 21.00 (2019) 
Tabel 3 di atas menghasilkan skordWsebesar 3,098untuk pengujian autokorelasi, dengan jumlah variabel independen (k) sebanyak 2 (dua) dan jumlah sampel (n) sebesar 7 (tujuh). Berdasarkan kriteria yang telah ditetapkan untuk syarat autokorelasi, maka masihterdapat autokorelasi karena skor dW lebih besar dari nilai 4-dU $(2,324<3,089)$. Oleh karenanya, dilakukan uji run test untuk mengobati autokorelasi.

Tabel 4

Hasil Uji Run Test

\begin{tabular}{cccc}
\hline Skor & Test Valuea & Nilai Z & Probabilitas \\
& 0,09514 & 0,910 & 0,363 \\
\hline
\end{tabular}

Sumber: Data diolah SPSS 21.00 (2019)

Tabel 4 di atas memperlihatkan bahwa probabilitas signifikansi lebih besar dari 0,05 $(0,363)$, yang artinya tidak terdapat masalah autokorelasi padaPT Indah Kiat Pulp \& Paper Tbk periode2012 2018 .

\section{Uji Korelasi}

Tabel 5

Hasil Uji KoefisienKorelasi (R)

\begin{tabular}{cccc}
\hline Variabel & CR & DER & ROE \\
\hline Person Correlations & 0,741 & 0,751 & 1 \\
Sig. & 0,028 & 0,026 & - \\
\hline
\end{tabular}

Sumber: Data diolah SPSS 21.00 (2019)

Tabel 5 di atas memperlihatkan bahwa signifikansi atas person correlations untuk menguji hubungan antaraCurrent Ratio (CR) dengan Return On Equity (ROE) yaitu 0,028 $<0,05$ yang berarti terdapat korelasi yang signifikan. Selanjutnya antara Debt to Equity Ratio (DER) dengan Return On Equity (ROE) nilai signifikansi $0.026<0,05$ yang berarti juga terdapat korelasi yang signifikan.Berdasarkan nilai korelasi antara Current Ratio (CR) terhadap Return On Equity (ROE) sebesar 0,741 yang berarti terdapat korelasi bersifat kuat. Selanjutnya antara Debt to Equity Ratio (DER) terhadap Return On Equity (ROE) sebesar 0,751 yang berarti terdapat korelasi bersifat kuat.

\section{Uji Hipotesis}

Tabel 6

Hasil Uji KoefisienDeterminasi (R2)

\begin{tabular}{ccccc}
\hline Model & $\mathbf{R}$ & $\mathbf{R}^{2}$ & Adjusted $\mathbf{R}^{2}$ & SE of the Estimate \\
1 & $0,842^{\mathrm{a}}$ & 0,708 & 0,563 & 2,95824 \\
\hline
\end{tabular}

Sumber: Data diolah SPSS 21.00 (2019)

Tabel 6 di atas memperlihatkan bahwa koefisien determinasi (R2) diperoleh sebesar 0,708, artinya 70,8 persen perubahan dari variabel Current Ratio (X1) dan Debt to Equity Ratio (X2) dijelaskan oleh variasi variabel Return On Equity (Y), sisanya 29,2 persen dijelaskan oleh variabel lain yang tidak diikusertakan.

Tabel 7

Rangkuman Hasil Uji-F

\begin{tabular}{cccc}
\hline Model & df & F & Sig. \\
1 & 2,4 & 14,529 & $0,015^{\mathrm{b}}$ \\
\hline
\end{tabular}

Tabel 7 di atas memperlihatkan bahwa Nilai F-hitung diketahui sebesar 14,529 dengan signifikansi 0,15 (lebih kecil dari alpha 5\%), sehingga menolak H0. Variabel Current Ratio (X1) dan Debt to Equity Ratio (X2) secara simultan berpengaruh terhadap variabel Return On Equity(Y). 
Wacana Ekonomi (Jurnal Ekonomi Bisnis dan Akuntansi), 19 (2) 2020, 106

Tabel 8

Rangkuman Hasil Uji t

\begin{tabular}{cccc}
\hline Model & Koefisien b & t & Sig. \\
\hline (Constant) & 10,772 & 0,861 & 0,438 \\
Current Ratio (X1) & 0,053 & 1,406 & 0,232 \\
Debt to Equity Ratio (X2) & $-0,067$ & $-1,475$ & 0,214 \\
\hline
\end{tabular}

Tabel 8 melalui uji-t (parsial) menghasilkan hasil persamaan regresi berganda sebagai berikut:

$\mathrm{Y}=10,772-0,053 \mathrm{X} 1-0,067 \mathrm{X} 2$

Constant : $\quad 10,772$. Artinya rata-rata kontribusi variabel independen selain X1 dan X2 juga memberikan dampak positif terhadap nilai Y.

X1 : 0,053. Artinya X1 memiliki pengaruh positif terhadap Y, jika terjadi kenaikan X1 sebesar 1 persen dan variabel independen lainnya bernilai tetap, maka $Y$ akan juga mengalami peningkatan sebesar 5,3 persen.

X2 : -0,067. Artinya X2 memiliki pengaruh positif terhadap Y, jika terjadi kenaikan X2 sebesar 6,7 persen dan variabel independen lainnya bernilai tetap, maka $\mathrm{Y}$ akan mengalami penurunan sebesar 6,7 persen.

\section{Pembahasan}

Variabel Current Ratio (X1) tidak memiliki pengaruh yang signifikan terhadap Return on Equity (Y) dengan probabilitas signifikansi sebesar 0,232 (lebih dari alpha 5 persen), temuan hasil ini bertolak belakang dengan penelitian yang membuktikan pengaruh negatif atas rasio perputaran kas terhadap profitabilitas dengan pengukuran ROI (Sapetu dkk., 2017), sementara sejalan dengan hasil yang tidak signifikan membuktikan pengaruh current ratio terhadap return on equity (Rahmah \& Asnawi, 2019). Hasil ini memberikan gambaran bahwaPT Indah Kiat Pulp \& Paper, Tbk tidak menjadikan current ratio sebagai faktor penentu dalam mengukur imbas hasil perusahaan dalam ekuitasnya. Rasio likuid ini tidak serta merta dapat dijadikan patokan oleh investor dalam mengambil keputusan investasi dalam konteks alat ukur yang lazim digunakan.

Variabel Debt to Equity Ratio (X1) dan Variabel Debt to Equity Ratio memiliki pengaruh simultan terhadap Return on Equity (Y) dengan probabilitas signifikansi sebesar 0,015 (kurangdari alpha 5 persen), temuan hasil ini sejalan dengan penelitian yang membuktikan pengaruh simultan atas current ratio dan debt to equity ratio terhadap return on equity (Rahmah \& Asnawi, 2019).

\section{SIMPULAN}

Simpulan penelitian ini adalah Current Ratio (X1) dan Debt to Equity Ratio (X2) dan secara simultan berpengaruh signifikan terhadap Return On Equity (Y) sementara secara parsial tidak terdapat pengaruh yang signifikan atas masing-masing Current Ratio (X1) dan Debt to Equity Ratio (X2) terhadap Return On Equity (Y). PT Indah Kiat Pulp \& Paper, Tbk hendaknya memperhatikan rasio profitabilitas lainnya seperti ROA, GPM dan EPS sebagai faktor yang mungkin dipertimbangkan dalam keputusan investasi. Hasil penelitian ini juga diharapkan dapat memberikan kontribusi dalam pengujian teori terapan, terutama dalam bidang manajemen keuangan mengenai pengaruh rasio lancar dan rasio solvabilitas terhadap profitabilitas yang menggambarkan kinerja perusahaandan dapat digunakan sebagai acuan untuk penelitian mendatang menggunakan proksi lainnya.

\section{DAFTAR PUSTAKA}

Arief, T. (2018). Sudah Naik 65\%, Simak Rekomendasi Saham Indah Kiat (INKP). Retrieved from https:// market.bisnis.com/read/20180130/189/732382/sudah-naik-65-simak-rekomendasi-saham-indah-kiatinkp 
Husain, T. (2019). An Analysis of Modeling Audit Quality Measurement Based on Decision Support Systems (DSS). European Journal of Scientific Exploration, 2(6). Retrieved from https:// www.syniutajournals.com/index.php/EJSE/article/view/128

Husain, T., Sarwani, Sunardi, N., \& Lisdawati. (2020). Firm's Value Prediction Based on Profitability Ratios and Dividend Policy. Finance \& Economics Review, 2(2), 13-26. doi:10.38157/finance-economicsreview.v2i2.102

Indrawati. (2015). Metode Penelitian Manajemen dan Bisnis Konvergensi Teknologi Komunikasi dan Informatika. Bandung: PT. Refika Aditama.

Kasmir, D. (2016). Analisis Laporan Keuangan. Jakarta: PT. Rajagrafindo Persada.

Kontan, H. (2019). Industri pulp dan kertas Indonesia. Retrieved from https://analisis.kontan.co.id/news/ industri-pulp-dan-kertas-indonesia

Pablo, S. (2018). Meski Masuk Era Digital, Permintaan Kertas Dunia Tetap Tumbuh. Retrieved from https:// www.cnbcindonesia.com/news/20180503135137-4-13493/meski-masuk-era-digital-permintaankertas-dunia-tetap-tumbuh

Rahmah, S., \& Asnawi, H. F. (2019). Pengaruh Current Ratio dan Debt to Equity Ratio terhadap Return of Equity pada Perusahaan yang Terdaftar dalam Jakarta Islamic Index (Studi di Sub-Sektor Telekomunikasi Periode 2013-2017). At-Taradhi: Jurnal Studi Ekonomi, 10(2), 202-213. doi:https:// dx.doi.org/10.18592/at-taradhi.v10i2.3285

Sapetu, Y., Saerang, I. S., \& Soepeno, D. (2017). Pengaruh Manajemen Modal Kerja terhadap Profitabilitas Perusahaan (Studi Kasus pada Perusahaan Makanan dan Minuman yang terdaftar di BEI periode 2011-2015). Jurnal EMBA: Jurnal Riset Ekonomi, Manajemen, Bisnis Dan Akuntansi, 5(2), 1440 1451. doi:https://doi.org/10.35794/emba.v5i2.16211

Shabrina, N. (2019). Analisis Rasio Profitabilitas dan Rasio Likuiditas untuk Menilai Kinerja Keuangan pada PT. Astra Internasional, Tbk. JIMF (Jurnal Ilmiah Manajemen Forkamma), 2(3). doi:10.32493/ frkm.v2i3.3398

Subramanyam, K. R. (2014). Financial Statement Analysis (11th ed.). New York: McGraw-Hill.

Sugiyono. (2018). Metode Penelitian Evaluasi: Pendekatan Kuantitatif, Kualitatif, dan Kombinasi. Bandung: CV. Alfabeta.

Wartono, T. (2018). Pengaruh Current Ratio (CR) dan Debt to Equity Ratio (DER) terhadap Return on Asset (ROA) (Studi pada PT Astra International, Tbk). Jurnal KREA TIFn Pemasaran, Sumberdaya Manusia Dan Keuangan, 6(2), 78-97. doi:http://dx.doi.org/10.32493/jk.v6i2.y2018.p78-97

Yanti. (2018). Analisa Pengaruh Faktor-Faktor Pembentuk Fee Ijarah (PSAK 107) terhadap Portofolio Rahn Emas di Bank Syariah. Jurnal Buana A kuntansi, 3(1), 24-55. doi:10.36805/akuntansi.v3i1.226 